\title{
O Bolsa Família e a tradução regional da questão social
}

\author{
[ The Bolsa Família Program and the regional translation of social question
}

\section{Tadeu Alencar Arrais ${ }^{\mathbf{I}}$}

Artigo vinculado ao projeto Transferência de renda direta e economia urbana: análise dos impactos da Aposentaria Rural e do Programa Bolsa Família nos municípios goianos (CNPq, 20I5-20I8).

RESUMO - O Programa Bolsa Família é uma resposta do Estado brasileiro ao problema da pobreza. Enquadra-se no espectro mais amplo da questão social. Os dados temporais são inequívocos quanto ao perfil regional das famílias beneficiadas. Argumentamos que esse perfil regional não é resultado de decisão governamental, mas de uma arquitetura do desenvolvimento dual do território brasileiro, ancorado em uma ideia de modernização regional que transformou a questão regional em uma das dimensões mais visíveis da questão social. $\mathrm{O}$ combate à pobreza, no entanto, não pode ser reduzido ao recorte regional, e a capilaridade do Bolsa Família no território nacional é prova inconteste dessa premissa. PALAVRAS-CHAVE.Bolsa Família; dualidade; questão regional; questão social. • ABSTRACT · The Bolsa Famí- lia Program is an answer of the Brazilian state for the problem of poverty. We can include it in the most broad spectrum of the social question. The temporal data are unmistakable in which concerns to the regional profile of the benefited families. We argue this regional profile is not result from the government decision, but by an architecture of dual development of the Brazilian territory, based in an idea of regional modernization which transformed the regional question in one of the most visible dimensions of the social question. The fight against poverty, however, can not be reduced to the regional scope, and the capillarity of the Bolsa Família program in the national territory is proof of this premise. - KEYWORDS - Bolsa Família Program; duality; regional question; social question.

Recebido em I3 de agosto de 2016

Aprovado em 8 de dezembro de 2016

ARRAIS, Tadeu Alencar. O Bolsa Família e a tradução regional da questão social. Revista do Instituto de Estudos Brasileiros, Brasil, n. 65, p. 200-226, dez. 2016.

DOI: http://dx.doi.org/Io.II6o6/issn.23I6-90IX.voi65p200-226

I Universidade Federal de Goiás (UFG, Goiânia, GO, Brasil). 
“Que Deus o proteja!” Esta expressão tão popular nos séculos de crença religiosa expressava o sentimento então compartilhado por toda a comunidade de que, para que a criatura humana estivesse verdadeiramente protegida contra todas as contingências da existência, era necessário que uma Onipotência tutelar a tomasse integralmente em suas mãos. Na falta desse fundamento absoluto da seguridade, agora cabe ao homem social a difícil tarefa de por si construir suas proteções ${ }^{2}$.

O Programa Bolsa Família, implementado pelo governo federal no ano de 2003, é caracterizado, de forma geral, pela universalidade, o que significa que qualquer cidadão que se enquadre nas chamadas condicionalidades terá a possibilidade de aderir ao programa. Os dados evolutivos dos benefícios apontam um inequívoco perfil regional das famílias beneficiadas, com presença destacada no Nordeste brasileiro. Trata-se, antes de uma opção eleitoral, de atender demandas ligadas ao histórico processo de integração regional brasileiro. Esse perfil regional é resultado da histórica arquitetura do desenvolvimento dual brasileiro, ancorado em uma ideia de modernização regional seletiva que transformou a questão regional em uma dimensão, possível de ser cartografada, da questão social brasileira. A dualidade, manifestada espacialmente pelos diversos graus de modernização do território e, socialmente, pelo acesso diferencial aos bens e serviços ofertados pelo Estado, foi marca histórica da paisagem social brasileira, fato fartamente registrado pela literatura acadêmica. Dito de outro modo, a pobreza brasileira ainda guarda uma epiderme regional, apesar dos avanços em sua redução registrados ao longo do último quartel do século XX. O Programa Bolsa Família, portanto, é compreendido a partir do mais amplo aspecto da questão social e, ao mesmo tempo, como uma política governamental que tenciona reduzir a pobreza. Essas duas características trazem implicações no discurso sobre a dualidade social e regional brasileira. Esse debate, como argumentamos, deve ser encarado a partir da histórica capitalização diferencial das regiões brasileiras pelo Estado.

2 CASTEL, Robert. La inseguridad social. ¿Qué estar protegido?. Buenos Aires: Manantial, 20I5, p. II3 (tradução nossa). 


\section{DUAS TRADIÇõES DO TERRITÓRIO HERDADO}

Há duas narrativas comuns sobre o território brasileiro que se fundem, de certo modo, em uma narrativa espacial de síntese. A primeira refere-se à dualidade do desenvolvimento e responde pela questão social. A segunda guarda relação com a tradução regional dessas dualidades e responde pela questão regional.

A dualidade, historicamente, funcionou como uma metáfora explicativa da sociedade brasileira. Rangel 3 interpretou essa dualidade na perspectiva dos "modos de produção", articulados entre polos internos e polos externos. Cada um dos polos é, igualmente, duplicado, o que oferece um retrato dinâmico da integração interna (nacional) que, por sua vez, responde aos determinantes da integração externa (internacional). Em cada dualidade reconhecemos a permeabilidade entre a economia e a política, razão por que, não por acaso, o escravismo encontra conforto na fazenda tradicional e no consequente poder oligárquico. A dualidade também despertou a atenção do sociólogo francês Jacques Lambert. $\mathrm{O}$ autor assume a ideia de que existem dois níveis diferenciais em uma nação, aparentemente, unitária. O primeiro nível, segundo Lambert ${ }^{4}$, apresentava uma "natureza arcaica", comprovada pela presença de condições de vida miseráveis. $\mathrm{O}$ segundo nível apresentava uma "natureza moderna”, cuja característica determinante era a velocidade na melhoria das condições de vida. O primeiro Brasil, arcaico, é demarcado pela pausa e pelo imobilismo do agrarismo. O segundo Brasil, moderno, é demarcado pela velocidade própria do mundo industrial que se insinuava em algumas parcelas do país, notadamente em São Paulo e no Rio de Janeiro.

Mas que Brasil era aquele de Jacques Lambert?

Aquele era, ainda, um país com marcas do período colonial. Um país cuja urbanização litorânea conviveu, de forma esparsa, com o povoamento interiorano, resultado da expansão da pecuária, de modo sistemático, e, de modo pontual, com o povoamento que remontava à mineração dos séculos XVII e XVIII. Não é demais lembrar que Minas Gerais, Goiás, Mato Grosso e Tocantins foram povoados na lógica pontual da mineração. O Brasil que rompe o século XIX e inaugura o século XX, ainda na tenra idade republicana, é um Brasil rural, mas que passa a conviver, desde então, com áreas urbanas cada vez mais dinâmicas que drenam, em variadas escalas, os excedentes produzidos no campo. Não deixa de impressionar que, em I920, o município de São Paulo abrigasse 579.033 pessoas, passando para I.326.26I habitantes em I9405.

O Brasil dual de Jacques Lambert é menos constrangedor que o retrato espacial da Geografia da fome de Josué de Castro ${ }^{6}$. O mapa da fome de Josué de Castro não é, propriamente, dual, muito embora os traços da regionalidade da fome endêmica e das epidemias de fome sejam inequívocos. As áreas de subnutrição predominam no que podemos, grosso modo, chamar de Centro-Sul brasileiro. As carências alimentares

3 RANGEL, I. A história da dualidade brasileira. Revista de economia política, v. I(4), out.-dez. I98I.

4 LAMBERT, Jacques. Os dois Brasis. Io. ed. São Paulo: Nacional, I978.

5 BRASIL. Recenseamento do Brasil realizado em Io de setembro de I920: população. Rio de Janeiro, I926; BRASIL. Recenseamento geral do Brasil I950. Rio de Janeiro: IBGE, I950.

6 CASTRO, Josué. Geografia da fome. II. ed. Rio de Janeiro: Gryp, I992. [I. ed., I946]. 
(vitaminas, proteínas, iodo, cloreto de sódio, anemias) espalham-se pelo país, conformando uma imagem perturbadora, que só encontrou paralelo na arte de Cândido Portinari. Não é coincidência que a conhecida tela a óleo do artista, Os retirantes, data do ano de I944, um pouco antes, portanto, de a Geografia da fome ser apresentada ao público.

A década de I950 inaugura uma espécie de auge do discurso da integração nacional. Um país com 5I.944.397 habitantes, com a maioria vivendo no campo e com $50,5 \%$ de analfabetos 7 , o que dá a ideia de que o desafio da integração não era, como se supôs, apenas territorial, mas também social. Não é por acaso que nesse período emergem os ideários da reforma agrária e da reforma urbana.

A integração pressupôs a presença do Estado na dotação de infraestrutura (ferrovias, estradas, energia, sistemas de estocagem etc.), o que permitiu a ampliação das trocas regionais, por um lado, e a drenagem de renda, por meio das trocas inter-regionais desiguais, por outro lado. Para isso já havia colaborado o fim dos impostos de exportação entre os estados, como expresso na Constituição de $1934^{8}$. O capital precisava circular sem barreiras jurídicas.
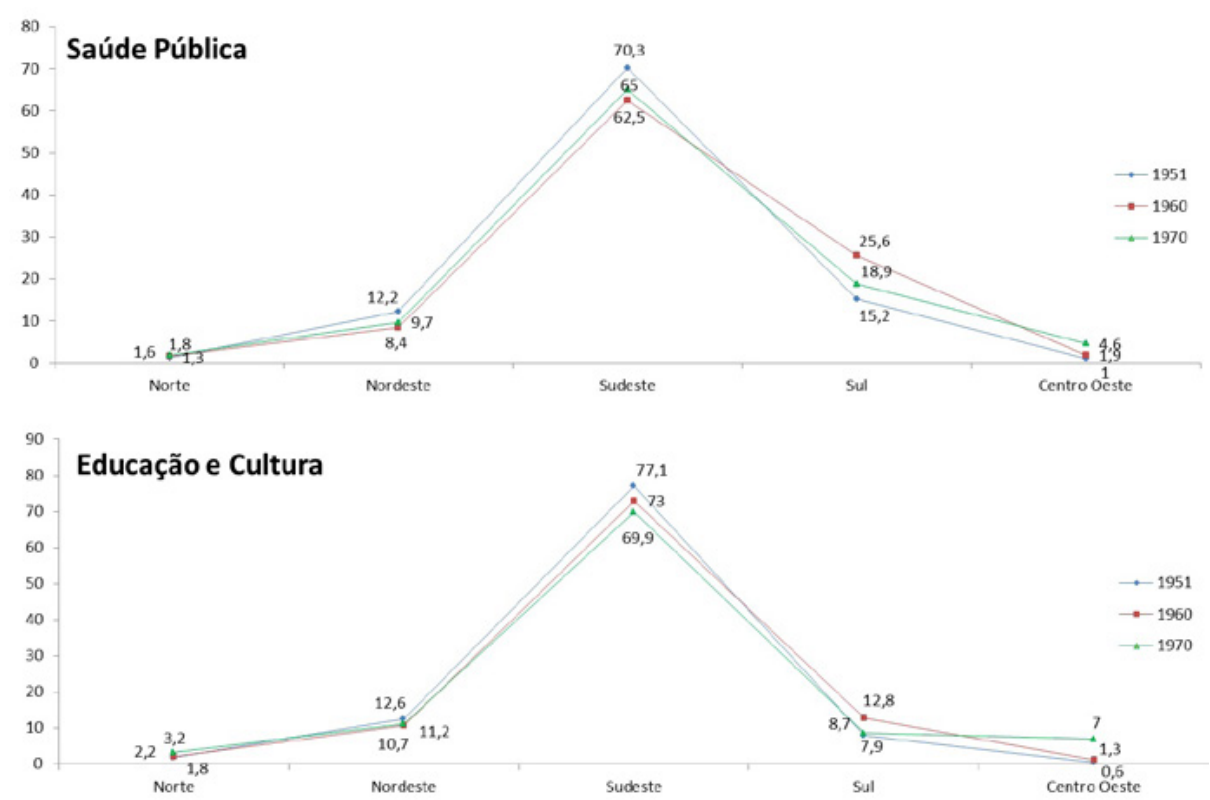

Figura I - Percentual de gasto público regional brasileiro em relação ao gasto público total do governo federal, em períodos selecionados. Fonte: elaboração do autor a partir de planilhas anexadas em artigo de MAIMON, Dália; GEIGER, P. Pinchass; BAER, Werner, I977

7 BRASIL. Instituto Brasileiro de Geografia e Estatística - IBGE. Censo demográfico de 20Io. Rio de Janeiro: IBGE, 2010.

8 BRASIL. Constituição da República dos Estados Unidos do Brasil-I934. Disponível em: <http://www.planalto.gov. br/ccivil_03/Constituicao/Constituica034.htm>. Acesso em: 20 jun. 2016. 
O esforço de integração nacional resultou na progressiva unificação do "mercado" de consumo e do mercado de mão de obra. O Sudeste, que havia emergido como região industrial, aparece como matriz positiva da dualidade brasileira. O Centro-Oeste ligou-se ao Sudeste por intermédio da modernização da agricultura, via consumo de maquinário e insumos agrícolas, e ao Nordeste, via migração inter-regional, especialmente para a edificação de Brasília. O investimento na integração territorial não resultou da mão invisível do mercado, agindo em uma planície isotrópica. Maimon, Geiger e Baer9 expuseram as diferenças regionais nos padrões de investimento e gastos do Estado entre I95I e I970. Do total do gasto do Plano Salte, $78 \%$ destinaram-se ao Sudeste. O I PND (Plano Nacional de Desenvolvimento) e o II PND destinaram para o Sudeste $56,99 \%$ e $58,88 \%$ dos gastos, respectivamente. Considerando os gastos públicos na saúde e na educação e cultura, os picos de investimentos se concentram no Sudeste, prova inconteste da capitalização dessa região pelo Estado, ação que aumentou as assimetrias regionais, especialmente em relação ao Nordeste, segunda região mais populosa.

Pouco mais de uma década após Josué de Castro publicar Geografia da fome $e^{\text {Io }}$, a questão nordestina aparece de forma sistematizada na agenda de atuação do governo federal, por meio do Grupo de Trabalho para o Desenvolvimento do Nordeste ${ }^{\text {II }}$. O GTDN institucionalizou, com base na racionalidade do planejamento regional, a dualidade do território brasileiro. A Sudene, herança do GTDN, funda uma espécie de visão racional, porque pautada em estudos técnicos, uma visão política, dada a ambição de intervenção do Estado brasileiro, e, principalmente, uma visão social, difundida por Celso Furtado. O Nordeste tornou-se o core da questão regional, como explicitado por Oliveira ${ }^{\mathrm{I} 2}$, e compôs, ao lado do Sudeste brasileiro, a liturgia da dualidade brasileira. A interpretação do Brasil dual encontrou, na metáfora utilizada por Francisco de Oliveira, uma explicação de como convivemos com a dualidade, representada pela figura do ornitorrinco. Um país cuja desigualdade é portadora de diferentes modernizações. Uma simbiose entre o que já adjetivamos de atraso e moderno. Assim se expressa Oliveira:

Como é o ornitorrinco? Altamente urbanizado, pouca força de trabalho e população no campo, dunque nenhum resíduo pré-capitalista; ao contrário, um forte agrobusiness. Um setor industrial da Segunda Revolução Industrial completo, avançado, tatibitate, pela Terceira Revolução, a molecular-digital ou informática ${ }^{\mathrm{T} 3}$.

9 MAINON, Dália; GEIGER, P. Pinchas; BAER, Werner. O impacto regional das políticas econômicas no Brasil. Revista brasileira de geografia, Rio de Janeiro, ano 39, n. 3, I977.

Io CASTRO, Josué, op. cit.

II GTDN-Grupo de Trabalho para o Desenvolvimento do Nordeste. Uma política de desenvolvimento econômico para o Nordeste. Rio de Janeiro: Departamento de Imprensa Nacional, I959.

I2 OLIVEIRA, Francisco de. A questão regional: a hegemonia inacabada. Estudos avançados, São Paulo, v. 7(I8), I993.

I3 Idem. Crítica à razão dualista: o ornitorrinco. São Paulo: Boitempo, 2003, p. I33. 
A narrativa da dualidade ocorreu em outras escalas. Milton Santos ${ }^{14}$ acentuou a convivência, na economia urbana, entre setores modernos, adjetivados de "circuito superior", e setores não modernos, adjetivados de "circuito inferior". No centro da leitura, mesmo na escala urbana, residia uma crítica relacionada à positividade do conceito de modernização. Foi a noção de positividade da modernização, associada às questões da conjuntura econômica da década de I990, que sepultou a Superintendência do Desenvolvimento do Nordeste (Sudene), resultando na criação, por intermédio da Medida Provisória n. 2.I46, de 4 de maio de 200I ${ }^{\mathrm{IS}}$, da Agência de Desenvolvimento do Nordeste (Adene). Uma agência, a julgar pela letra da lei, limitada ao ordenamento de incentivos fiscais por intermédio do Fundo de Desenvolvimento do Nordeste (FDNE). Se, no liberalismo, os indivíduos são responsáveis por seu destino, a mesma premissa serviria para as regiões. No mundo global, que assiste, em tese, à erosão dos estados nacionais, as corporações aparecem como ordenadoras das regiões que passam a responder por um projeto global de competividade. A política regional, no início da década de I990, perdeu substância para a retórica da internacionalização via Eixos Nacionais de Desenvolvimento, em trajetória analisada por Araújo ${ }^{\mathrm{T}}$.

O Brasil do início dos anos 2000 é tão distinto daquele da década de I950 quanto o são os mecanismos metodológicos de mensuração dos graus de desenvolvimento. A análise da figura 2 conduz para duas questões. A primeira delas é a velocidade das mudanças. Em I99I, 85,8\% dos municípios brasileiros encontravam-se no intervalo denominado de faixa de baixo de desenvolvimento municipal, percentual reduzido para 4I,8\% em 2000 e $0,6 \%$ em $2010^{17}$. A faixa média de desenvolvimento municipal, em 2010, predominava, abrangendo 40,I\% dos municípios brasileiros, o que é bastante superior

I4 SANTOS, M. O espaço dividido. Rio de Janeiro: Francisco Alves, I979.

I5 BRASIL. Medida Provisória n. 2.I46-I, de 4/5/200I. Cria as Agências Desenvolvimento da Amazônia e do Nordeste, extingue a Superintendência do Desenvolvimento da Amazônia - Sudam e a Superintendência do Desenvolvimento do Nordeste - Sudene, e dá outras providências. Disponível em: <http://www.planalto.gov. br/ccivil_03/MPV/2I46-I.htm>. Acesso em: I8 maio 2016.

I6 ARAÚJO, T. Bacelar de. Ensaios sobre o desenvolvimento brasileiro. Rio de Janeiro: Revan, 2000.

I7 Existem outros modos de mensurar o grau de desenvolvimento de um recorte geográfico determinado. Utilizamos o Índice de Desenvolvimento Humano Municipal (IDHM) como referência, uma vez que o estudo abrange o território nacional e, a partir dos mapas, é possível estabelecer padrões comparativos. O IDHM, segundo o Programa das Nações Unidas para o Desenvolvimento (PNUD, 20Io), “Populariza a ideia de que desenvolvimento não se resume à perspectiva do crescimento econômico, mas sim facilita a comparação entre localidades, conduz a um diálogo mais informado na discussão de políticas e estimula a busca de melhores desempenhos socioeconômicos entre os municípios e regiões metropolitanas brasileiras. O índice não abrange todos os aspectos de desenvolvimento humano e não é uma representação da 'felicidade' das pessoas, nem indica 'o melhor lugar no mundo para se viver', mas sintetiza três das mais importantes dimensões do desenvolvimento humano. Amplia e fomenta o debate, instrumentalizando a sociedade sobre o estado da qualidade de vida nas unidades federativas, municípios, regiões metropolitanas e UDHs brasileiras, estimulando a concertação de atores de forma a protagonizar atividades e políticas inovadoras para a superação dos desafios locais rumo ao desenvolvimento humano". PNUD - Programa das Nações Unidas para o Desenvolvimento. Atlas do desenvolvimento municipal (20I0). Disponível em: <http://www.atlasbrasil. org.br/20I3/>. Acesso em: I5 maio 2016. 
ao $0,8 \%$ registrado na mesma faixa de desenvolvimento em I99I. Em dezenove anos o mapa do desenvolvimento municipal mudou completamente suas feições. A segunda questão é que persiste um perfil regional dos níveis de desenvolvimento municipal. No Nordeste registra-se, ainda, uma considerável presença da faixa de baixo desenvolvimento municipal, seguido da faixa de médio grau de desenvolvimento municipal. Não havia registro, em 20Io, no Norte e Nordeste, de municípios na faixa de muito alto grau de desenvolvimento municipal. No Centro-Oeste, apenas o Distrito Federal situou-se nessa faixa.
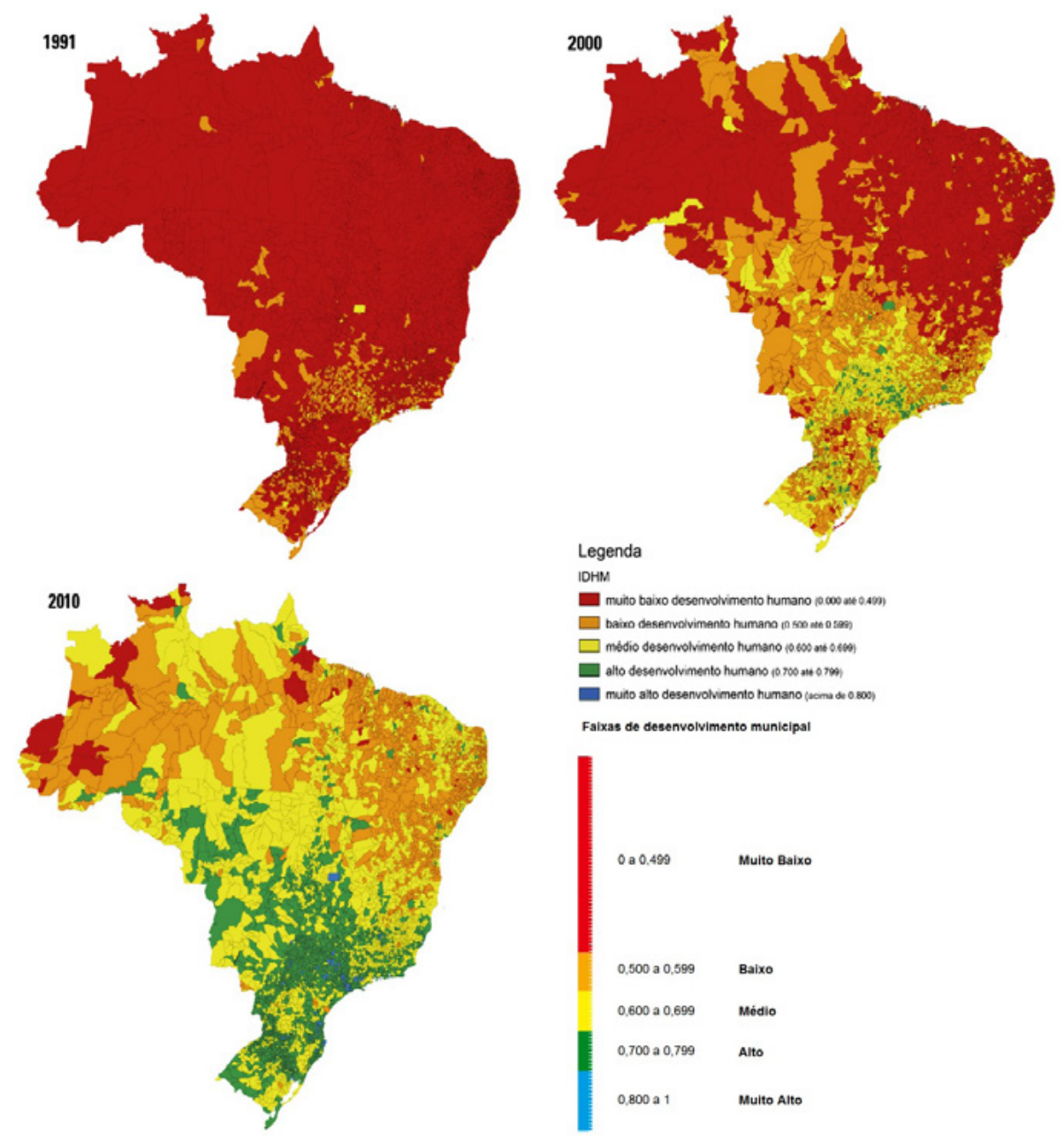

Figura 2 - Evolução das faixas de desenvolvimento municipal, Brasil. Fonte: PNUD, 20Io 
Estudo desenvolvido pelo Instituto de Pesquisa Econômica Aplicada (Ipea), intitulado "A década inclusiva (200I-20II)"ז8, corrobora as mudanças expressas na cartografia do desenvolvimento municipal. De acordo com o estudo, o Nordeste cresceu mais que São Paulo, a renda rural aumentou mais que a renda urbana e os grupos formados por pretos e pardos foram mais beneficiados com os acréscimos relativos de renda que os brancos. As razões para esses avanços relacionam-se ao aumento do salário mínimo e ao controle inflacionário. Entre 2004 e 20I5, apenas no último ano (20I5) a inflação registrada foi maior que o reajuste do salário mínimo. O reajuste acumulado do salário mínimo no período atingiu I25,45\%, contra 72,34\% de inflação acumulada ${ }^{\mathrm{T}}$. Não é sem motivo que, entre as causas da equidade, a pesquisa do Ipea assinale a contribuição da renda proveniente do trabalho (58\%), da Previdência (I9\%), do Bolsa Família (I3\%) e do Benefício de Prestação Continuada (4\%). A título de comparativo, no ano de 20I5, o desembolso com a Aposentadoria Rural atingiu R\$ 86.I49.871.890,00 ${ }^{20}$, contemplando 9.346.364 pessoas. No mesmo ano, o desembolso para o Bolsa Família atingiu R\$ 25.378.505.00o,oo, contemplando I3.782.2I7 famílias. A redução da desigualdade entre 200I e 20II, manifestada pela diminuição da pobreza, estimulou o debate nacional sobre a questão social. Nesse sentido, nenhum programa governamental contemporâneo recebeu tanta atenção na esfera política, econômica e acadêmica quanto o Bolsa Família.

\section{O Bolsa Família e a Questão social}

O retrato espacial herdado da década de 2000 pode ser interpretado de várias maneiras. Admitimos certo encaixe entre os arranjos regionais, representados pelas regiões, e a centralidade da questão social, representada pelas discussões sobre a função do Estado na condução das políticas sociais. É nesse momento que emerge, como uma variante da questão social, o programa Bolsa Família. Mas o que caracteriza uma questão social? Robert Castel, em As metamorfoses da questão social, elabora uma espécie de genealogia da questão social.

I8 IPEA - Instituto de Pesquisa Econômica Aplicada. A década inclusiva (200I-20II): desigualdade, pobreza e políticas de renda. Comunicados do Ipea, Brasília, n. I55, 25 de setembro de 2012.

I9 $\mathrm{BCB}$ - Banco Central do Brasil. Histórico de metas para a inflação no Brasil. 20I6. Disponível em: <http:// www.bcb.gov.br/Pec/metas/TabelaMetaseResultados.pdf $>$. Acesso em: 20 jun. 20I6; MTPS - Ministério do Trabalho. Evolução do salário mínimo - Legislação - I960-20I6. 20I6. Disponível em: <http://www.mtps.gov. br/salario-minimo/evolucao-salario-minimo >. Acesso em: 20 jun. 2016.

20 MTPS - Ministério do Trabalho. Arrecadação e benefícios emitidos pela Previdência Social nos municípios brasileiros, 20I5. Brasília: MTPS, 20I5. Disponível em: <http://www.mtps.gov.br/ dados-abertos/dados-da-previdencia/previdencia-social-e-inss/previdencia-estatistica-por-municipio/ estatisticas-municipais-20I4>. Acesso em: Io jun. 2016. 
A “questão social” é uma aporia fundamental sobre a qual uma sociedade experimenta o enigma de sua coesão e tenta conjurar o risco de sua fratura. É um desafio que interroga, põe em questão a capacidade de uma sociedade (o que, em termos políticos, se chama uma nação) para existir como um conjunto ligado por relações de interdependência ${ }^{2 \mathrm{~T}}$.

A questão social apresenta, ao mesmo tempo, uma dimensão abstrata, derivada do legítimo questionamento da sociedade sobre a participação dos diferentes grupos sociais na construção da nação, e uma dimensão concreta, resultado da forma como o Estado nacional insere as demandas sociais em sua agenda de atuação. A questão social, portanto, liga-se ao Estado social, aparelho centralizador das redes de proteção social. Parece estar claro que, desde o anúncio da modernidade, ainda no século XIX, o Estado implementou redes de proteção em resposta, por exemplo, ao pauperismo ou mesmo às precárias condições de trabalho na Europa central. Castel ${ }^{22}$ centra energias no universo europeu e, especialmente, na questão do trabalho. Wanderley ${ }^{23}$ (2OI5) recorda que, no caso da América Latina, com determinantes históricos, econômicos e culturais distintos, outros temas, como a questão indígena, a inclusão dos negros e mulheres e mesmo a inserção dos trabalhadores rurais na agenda de preocupações do Estado, constituíram temas fundamentais para a questão social. O paralelismo com o debate europeu se localiza na questão da coesão social, que, em determinadas circunstâncias históricas, se manifestou naquele continente a partir da inclusão via trabalho assalariado, processo que se apresentou de forma mais tardia no Brasil.

No percurso de sua agenda de atuação no território, o Estado não aparece como uma unidade autônoma em relação ao mercado, daí o fato de as diferentes concepções de Estado repercutirem, historicamente, na questão social. Harvey ${ }^{24}$, ao se referir às políticas sociais no neoliberalismo, classifica-as de "redistribuição via Estado". A questão de fundo, como enfatiza Harvey, reside na compreensão do conceito e da forma de ação do Estado na sociedade capitalista. É ingenuidade supor, como alertou Offe ${ }^{25}$, que a "acumulação capitalista" prescinda da presença do Estado, pois sua eliminação da arena política causaria mais problemas que soluções. As concepções liberais, como aquelas divulgadas por $\mathrm{Hayek}^{26}$, no conhecido $\mathrm{O}$ caminho da servidão, camuflam, em nome da liberdade, o fato de as ações do Estado serem funcionais para o mercado. Moraes e Silva ${ }^{27}$ alegam que, mesmo na chamada "pátria do mercado",

2I CASTEL, Robert. As metamorfoses da questão social. Petrópolis, 20I5, p. 30.

Idem. La inseguridad social. ¿Qué estar protegido?, op. cit.

WANDERLEY, L. Eduardo W. A questão social no contexto da globalização: o caso latino-americano e o caribenho. In: CASTEL, Robert; WANDERLEY, Luiz Eduardo W.; BELFIORE-WANDERLEY, Mariangela. Desigualdade e a questão social. 4. ed. São Paulo: Educ, 2015.

24 HARVEY, David. O neoliberalismo. São Paulo: Loyola, 2008.

25 OFFE, Clauss. Trabalho e sociedade. V. 2. Rio de Janeiro: Tempo Brasileiro, I99I.

26 HAYEK, F. August. O caminho da servidão. 5. ed. Rio de Janeiro: Instituto Liberal, I990.

27 MORAES, R. Carmelo Correa; Silva, M. de Paula e. O peso do Estado na pátria do mercado. São Paulo: Ed. Unesp, 20I4. 
os Estados Unidos da América, o papel do Estado foi decisivo na distribuição da infraestrutura e regulação dos mercados, fundamentalmente durante o século XIX e os primeiros quartéis do século XX. Nem mesmo Milton Friedman ${ }^{28}$ conseguiu ocultar a atuação do Estado na economia americana, daí reproduzir um repertório de reclamações sobre os subsídios para a agricultura, a regulação da indústria, os programas de seguridade, a educação pública, o salário mínimo etc. Não é por ironia que Polanyi ${ }^{29}$ diz que existe um conteúdo utópico no liberalismo.

Na Europa, especialmente após os Gloriosos Trinta, o debate sobre o papel do Estado social ganhou centralidade, uma vez que o acelerado crescimento do pós-guerra, expresso nos baixos níveis de desemprego e na universalização dos serviços públicos, entrara em declínio. A universalização dos serviços públicos e os direitos sociais foram colocados em xeque. No entanto, a universalização dos serviços públicos não resume as diferentes redes de proteção social. Os chamados Programas de Transferências de Renda são um exemplo. Na América Latina, como indicado em

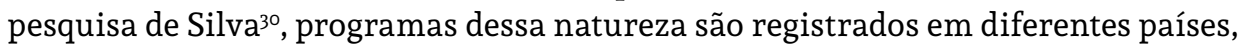
a exemplo de Honduras (I990), Colômbia (2000), México (2000), Chile (2000) e mais recentemente Guatemala (20I2).

No Brasil contemporâneo, o marco formal da assistência social foi a Lei Orgânica de Assistência Social (Loas), publicada em 7/I2/I993.

Art. $\mathrm{I}^{\circ} \mathrm{A}$ assistência social, direito do cidadão e dever do Estado, é Política de Seguridade Social não contributiva, que provê os mínimos sociais, realizada através de um conjunto integrado de ações de iniciativa pública e da sociedade, para garantir o atendimento às necessidades básicas ${ }^{31}$.

A relação entre direito e dever deve ser compreendida a partir da função dos atores na arena política. A centralidade de uma assistência social não contributiva e sem condicionalidades se expressa na proteção social, de forma abstrata, e de forma concreta, por exemplo, na garantia de I salário mínimo de benefício mensal às pessoas deficientes ou mesmo a idosos que não possuem meios para prover as demandas diárias. É o que se chama de Benefício de Prestação Continuada. A Loas, associada às mudanças na seguridade social referendadas na Constituição de I988 ${ }^{32}$, que previu aposentadoria não contributiva para pequenos produtores, parceiros, meeiros, arrendatários rurais, garimpeiros, pescadores artesanais, ampliou sobremaneira a rede de proteção social. Kersternetzky33 lembra que a partir de I988, no ambiente da nova

28 FRIEDMAN, Milton. Capitalismo e liberdade. Rio de Janeiro: Artenova, I977.

29 POLANYI, K. A grande transformação: as origens de nossa época. Rio de Janeiro: Campus, 2000.

30 SILVA, Maria O. da Silva. Programas de transferência de renda na América Latina e Caribe. São Paulo: Cortez, 2014 .

3I BRASIL. Lei n. 8.742, de 7/I2/I993. Dispõe sobre a organização da Assistência Social e dá outras providências.

Disponível em: 〈http://www.planalto.gov.br/ccivil_03/leis/L8742compilado.htm〉. Acesso em: I6 maio 2016.

32 BRASIL. Constituição da República Federativa do Brasil I988. São Paulo: Saraiva, I99I.

33 KERSTENETZKY, Celia Lessa. O Estado do Bem-Estar Social na idade da razão. Rio de Janeiro: Elsevier, 20I2 
Constituição Federal, ocorreu uma expansão dos direitos sociais, acompanhada de novas formas de financiamento público. Segundo a autora:

De fato, as políticas sociais são imediatamente afetadas pelas prescrições constitucionais no campo da seguridade social, que passa a abranger a previdência, a assistência social e a saúde. Incluem-se entre as medidas mais importantes a criação do seguro-desemprego, a criação do Sistema Único de Saúde (SUS), a aplicação de novas regras universalizantes da Previdência Rural e a regulamentação da assistência social "cidadã" - o reconhecimento, enfim, da responsabilidade pública por vários riscos socais, antigos e novos, e pela "promoção, proteção e recuperação da saúde" 34 .

No início da década de I990, o senador Eduardo Suplicy protagonizou debates no Senado Federal durante a tramitação do projeto de lei denominado Programa de Garantia de Renda Mínima35. Suplicy cita, com frequência, paralelos com o Imposto de Renda Negativo. Resumidamente, esse imposto consistiria em estabelecer um teto de renda mínima, abaixo do qual haveria, por parte do Estado, uma complementação de renda monetária. Friedman explora essa ideia, opinando que esse imposto seria mais funcional para o mercado do que os vastos e dispersos programas de assistência social: "É de ordem geral e pode substituir o grande conjunto de medidas atualmente existente" ${ }^{36}$. O Imposto de Renda Negativo, a despeito do entusiasmo de Suplicy por Friedman, não existiria a partir do Estado Social, mas sim da erosão daquilo que ele tem de essencial, que são as redes de proteção social e a oferta de serviços públicos. É preciso considerar, teoricamente, que a adoção de um Imposto de Renda Negativo para financiar transferências de renda, por exemplo, não deveria eliminar o investimento estatal em serviços ligados a saúde e educação e, de forma mais ampla, o investimento em assistência social.

É nesse contexto político geral, envolvendo uma concepção geral de Estado pós-Constituição de I988, que surge o Bolsa Família, em 2003. A mudança no período de democratização foi significativa, envolvendo, do ponto de vista político, uma espécie de pacto de solidariedade e, do ponto de vista econômico, a afirmação da função redistributiva do Estado. No contexto particular, caracterizou-se pela emergência de um governo que assume a questão social como central em sua agenda política.

Dez meses após assumir a Presidência da República, o presidente Luiz Inácio Lula da Silva lançou o Programa Bolsa Família ${ }^{37}$, unificando os programas Bolsa Escola, Programa Nacional de Acesso à Alimentação (PNAA), Bolsa Alimentação e Programa Auxílio-Gás. Classificado como transferência de renda com condicionalidades, prevê benefícios básicos e benefícios variáveis, diferenciados pela situação de extrema

34 Ibidem, p. 2I7.

35 SUPLICY, E. Programa de Garantia de Renda Mínima. Brasília: Senado Federal, I992.

36 FRIEDMAN, Milton, op. cit., p. I62.

37 BRASIL. Medida Provisória n. I32, de 20/Io/2003. Cria o Programa Bolsa Família e dá outras providências. Disponível em: 〈http://www.planalto.gov.br/ccivil_o3/mpv/Antigas_2003/I32.htm〉. Acesso em: 25 maio 2016. 
pobreza e pobreza. Isso significa que as transferências são focalizadas com base em uma definição instrumental de pobreza.

\begin{tabular}{|c|c|c|c|c|c|c|c|}
\hline \multirow[t]{2}{*}{ Benefício } & \multirow{2}{*}{\multicolumn{2}{|c|}{ Destinação }} & \multicolumn{2}{|c|}{$\begin{array}{l}\text { Valor mensal } \\
\text { (R\$) }\end{array}$} & \multirow[t]{2}{*}{ Unidade } & \multicolumn{2}{|c|}{$\begin{array}{c}\text { Limite de } \\
\text { renda per capita } \\
\text { familiar (RS) }\end{array}$} \\
\hline & & & 2004 & 2015 & & 2004 & 2015 \\
\hline Básico & Extr & obreza & 50,00 & 77,00 & Família & 50,00 & 154,00 \\
\hline Variável & $\begin{array}{l}\text { Pobreza e } \\
\text { extrema } \\
\text { pobreza }\end{array}$ & $\begin{array}{l}\text { Gestantes, } \\
\text { nutrizes, } \\
\text { crianças de } \\
0 \text { a } 12 \text { anos e } \\
\text { adolescentes } \\
\text { até } 15 \text { anos }\end{array}$ & $15^{*}$ & $35^{*}$ & Beneficiário & 100,00 & 77,00 \\
\hline
\end{tabular}

Tabela I - Valores nominais dos benefícios básicos e variáveis de 2004

e 20I5. Fonte: elaboração do autor com base em BRASIL, 2003, 2014

*Até 3 benefícios por família

** Até 5 benefícios por família

É necessário considerar duas questões em relação ao Bolsa Família. A primeira é que se trata de um programa recente, o que implica considerar um intervalo de doze anos desde que foram executadas as primeiras transferências para as famílias em situações de pobreza e de extrema pobreza. A segunda é a dimensão do território brasileiro, marcado por diferenças de acesso aos serviços públicos, de níveis de renda, emprego, escolaridade etc. É oportuno recordar que estamos tratando de um país de dimensões continentais, fragmentado por 5.565 municípios e com contextos ecológicos diferenciados. Do total, 3.92I municípios tinham população de até 20.000 habitantes no ano de $2010^{38}$. É sobre esse território que se criou uma rede de assistência social que exige, além de recursos, um aparato técnico-burocrático para colocar em funcionamento o programa social com maior capilaridade nacional.

38 Idem. Instituto Brasileiro de Geografia e Estatística - IBGE. Censo demográfico 20Io. Rio de Janeiro: IBGE, 2010. 


\begin{tabular}{|l|l|l|}
\hline \multirow{2}{*}{ Dimensão } & \multicolumn{2}{|c|}{ Críticas } \\
\cline { 2 - 3 } Social & $\begin{array}{l}\text { Positivas } \\
\text { Eficaz no combate à pobreza a partir } \\
\text { da focalização em grupos específicos } \\
\text { e exigência de condicionalidades na } \\
\text { área de saúde e educação. }\end{array}$ & $\begin{array}{l}\text { Estimula a cultura do não trabalho, } \\
\text { tradicional fonte da riqueza, e não } \\
\text { apresenta garantias do cumprimento } \\
\text { das condicionalidades. }\end{array}$ \\
\hline \multirow{2}{*}{ Política } & $\begin{array}{l}\text { Estimula a autonomia dos indivíduos, } \\
\text { com foco especial no gênero, o que } \\
\text { contribui para romper os laços } \\
\text { políticos horizontais do clientelismo } \\
\text { localista. }\end{array}$ & $\begin{array}{l}\text { Estimula o clientelismo a partir da } \\
\text { esfera federal, o que conforma situações } \\
\text { de populismo político, indicado pela } \\
\text { regionalidade dos votos. }\end{array}$ \\
\hline \multirow{2}{*}{ Econômica } & $\begin{array}{l}\text { Baixo custo e efeito capilar na escala } \\
\text { local e regional, manifestado, por } \\
\text { exemplo, pelo aumento do consumo } \\
\text { no varejo. }\end{array}$ & $\begin{array}{l}\text { Gasto público improdutivo, } \\
\text { comprometido, ainda, pela ineficiência } \\
\text { dos mecanismos de controle. }\end{array}$ \\
\hline
\end{tabular}

Quadro I - Síntese das principais críticas ao Programa Bolsa Família. Fonte: elaboração do autor

Do quadro geral de críticas descritas emergiu farta literatura. Temas como o impacto no núcleo familiar e nas relações de gênero, ou mesmo seus efeitos na conjuntura política, demarcada pelo que alguns, como Martins ${ }^{39}$, chamam de estatização do clientelismo, são recorrentes. Na sociologia existem estudos com foco nos efeitos das transferências de renda nos grupos sociais, de maneira geral, e na mobilidade social dos indivíduos, de maneira específica. Rego e Pinzani ${ }^{40}$ desenvolveram primoroso estudo sobre os impactos do Bolsa Família nas relações de gênero e na qualidade de vida das famílias beneficiadas. Na linha dos efeitos econômicos, estudo do Ipea aponta que, a cada R I gasto com o Bolsa Família, R\$ I,78 é incorporado ao PIB ${ }^{4 I}$. Há estudos que procuram desmistificar as críticas ao programa Bolsa Família partindo de uma reflexão sobre os efeitos positivos das condicionalidades (frequência escolar, acompanhamento do pré-natal e do calendário imunológico) e da consequente inserção das famílias beneficiadas no mercado de trabalho formal. Sobre essa última questão, Medeiros, Britto e Soares escrevem:

39 MARTINS, José de Souza. A política do Brasil. São Paulo: Contexto, 20II.

40 REGO, Walquiria L.; PINZANI, Alessandro. Vozes do Bolsa Família. São Paulo: Ed. Unesp, 2013.

4I NERI, Marcelo Cortes; VAZ, Fábio Monteiro; SOUZA, P. Herculano G. Efeitos macroeconômicos do programa Bolsa Família: uma análise comparativa das transferências sociais. In: CAMPELLO, Tereza; NERI, Marcelo Côrtes (Org.). Programa Bolsa Família: uma década de inclusão e cidadania. Brasília, Ipea, 2013. 
O fato é que tomar as transferências como um desestímulo ao trabalho é uma ideia que pode ser fundamentada em preconceitos, mas não se apoia em evidências empíricas. Dados recentes do Instituto Brasileiro de Geografia e Estatística (IBGE) mostram que pessoas que vivem em domicílios onde há beneficiados do Bolsa Família trabalham tanto ou mais que outras pessoas com renda familiar per capita similar ${ }^{42}$.

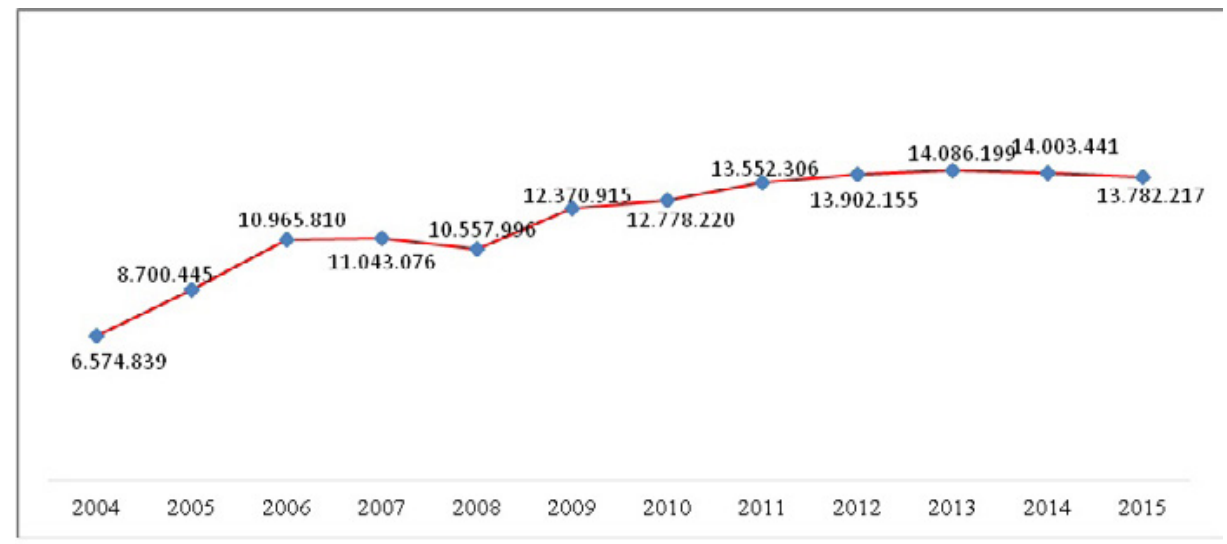

Figura 3 - Evolução temporal do número de famílias contempladas no Bolsa Família, Brasil. Fonte: dados trabalhados pelo autor a partir de DATA-SOCIAL, 2016

No intervalo de onze anos o número de famílias beneficiárias mais que dobrou, chegando em 2015 a I3.782.2I7 famílias. Se o número de famílias cresceu I25\% entre 2004 e 20I5, o crescimento percentual no valor desembolsado ultrapassou $260 \%$, passando de $\mathrm{R} \$$ 6.574.839.000,00, em 2004, para R\$25.378.505.000, em 2015 . Mas a evolução no número de famílias, apesar de considerável, ainda não atesta a capilaridade do Bolsa Família. O número que surpreende refere-se ao total de beneficiários envolvidos diretamente nas transferências. Em 20I5 havia 47.I46.438 pessoas diretamente beneficiadas, sendo 2I.I76.069 homens e 26.8I8.672 mulheres. Considerando que a população do Brasil, em 20I5, era de 204.450.649, chegamos à proporção de $23 \%$ da população envolvida nessa rede de proteção social. Desse total, 40,5\% tinham idade de até I4 anos. No corte étnico, 0,9\% era indígena, 6,5\% eram negros e $67 \%$ eram pardos.

42 MEDEIROS, Marcelo; BRITTO, Tatiana; SOARES, Fábio. Transferência de renda no Brasil. Novos Estudos - Cebrap, São Paulo, n. 79, 2007, p. I5. Disponível em: <http://www.scielo.br/scielo.php?pid=SoIOI$33002007000300001 \&$ script=sci_arttext $>$. Acesso em: I5 nov. 2007. 


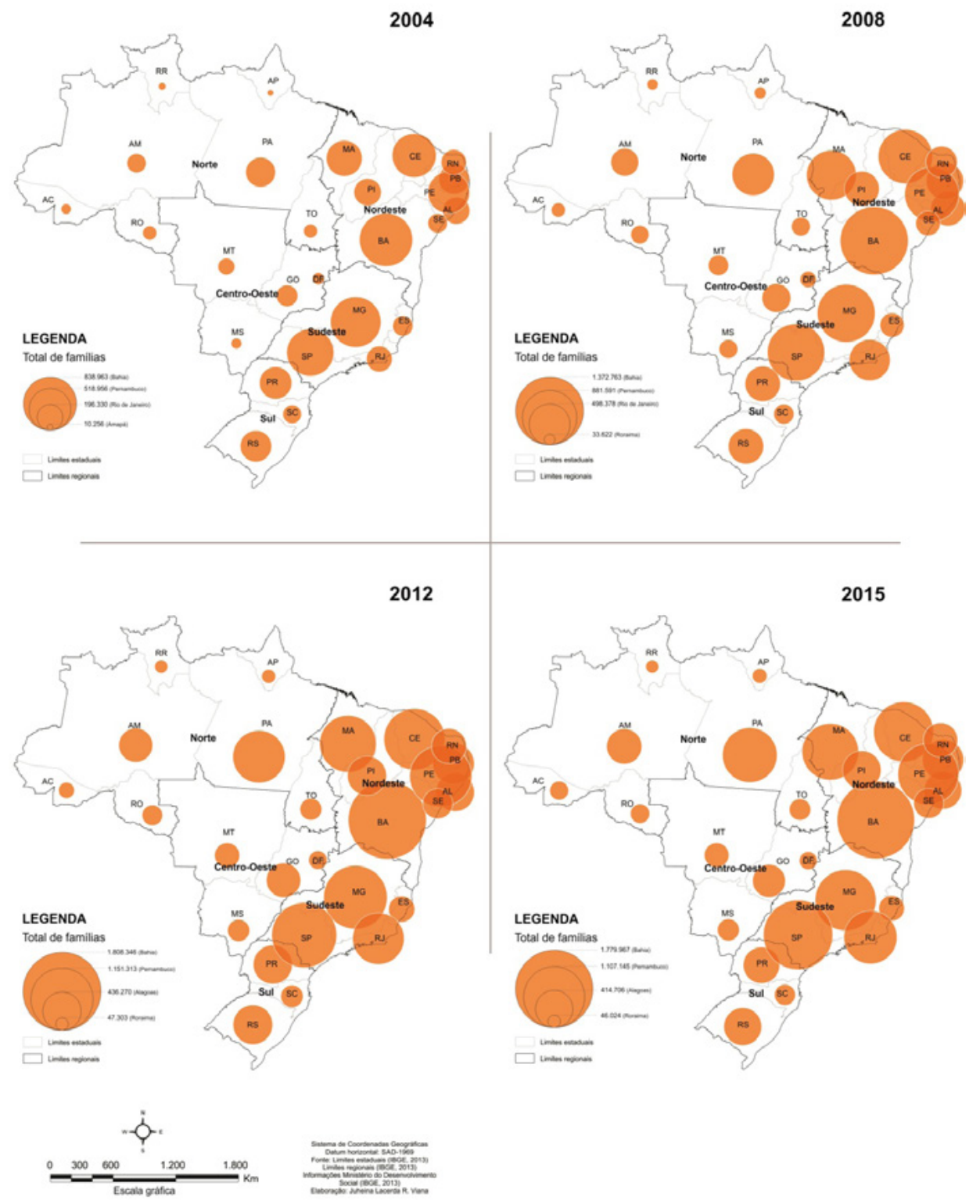

Figura 4-Evolução, por estado, do número de famílias beneficiadas pelo Bolsa Família. Fonte: elaboração do autor a partir de DATA-SOCIAL, 2016

Mas a capilaridade não estaria completa sem a referência à rede técnica burocrática envolvida diretamente com o Bolsa Família. Em 2007 havia 4.I95 Centros de Referência de Assistência Social (Cras), número que passou para 8.09I, em 20I4, 
com cobertura de $98,5 \%$ dos municípios brasileiros ${ }^{43}$. O número de trabalhadores nas secretarias municipais de Assistência Social saltou de 220.730, em 2007, para 256.858, em 20I4. A assistência social ainda não resume a rede de trabalhadores que gravitam no Bolsa Família. É necessário considerar a rede de atendimento centralizada na Caixa Econômica Federal, como Agências Convencionais, Caixa Aqui, Agências Lotéricas, Agências-Barco ${ }^{44}$. A presença dessa rede de serviços é mais um dos indicadores da capilaridade do Bolsa Família.

\section{O retrato regional do Bolsa Família}

No ano de 2004, o Nordeste concentrava 5I\% das famílias beneficiadas e $57 \%$ do valor destinado ao Bolsa Família. O Sudeste respondia por $26 \%$ do total de famílias e $22 \%$ do valor destinado. Para o Nordeste foram destinados R\$ 2.I73.475.460,00, e para o Sudeste, R\$ 824.748.603,00. O Centro-Oeste obteve a menor participação no número de famílias, com $4 \%$ do total do Brasil. Independente das diferenças de cobertura que se reproduzem na escala intrarregional, o Bolsa Família atingiu a totalidade dos municípios brasileiros. Os dados regionais de 2015 atestam diferença insignificante em relação ao ano de 2004. A participação do Nordeste, que era de $51 \%$ no valor em 2004, reduziu para $49 \%$ em 2015 . A participação do Sudeste, que chegou a $26 \%$ em 2004, reduziu para $25 \%$ em 20I5. Coube ao Norte registrar o maior crescimento, concentrando $8 \%$ dos beneficiários em 2004 e I4\% em 20I5. A Região Sul, cuja participação no total de famílias beneficiadas era de II\% em 2004, reduziu sua participação para $7 \%$, em 2015.

A participação diferencial das regiões será interpretada a partir de três dados: I) pelas faixas de renda das famílias incluídas no Cadastro Único; 2) pela relação entre a população total, o número de beneficiados e o total de famílias; 3) pela quantidade de famílias beneficiadas por grupos populacionais tradicionais e específicos.

43 BRASIL. Lei n. I2.435, 6/7/20II. Altera a Lei n. 8.742, de 7 de dezembro de I993, que dispõe sobre a organização da Assistência Social. Disponível em: <http://www.planalto.gov.br/ccivil_03/_ato20II-20I4/20II/lei/lI2435. $\mathrm{htm}>$. Acesso em: I8 maio 2016.

$44 \mathrm{CEF}$ - Caixa Econômica Federal. Atendimento. Disponível em: <http://www.caixa.gov.br/sobre-a-caixa/ Paginas/default.aspx>. Acesso em: I8 maio 2016. 


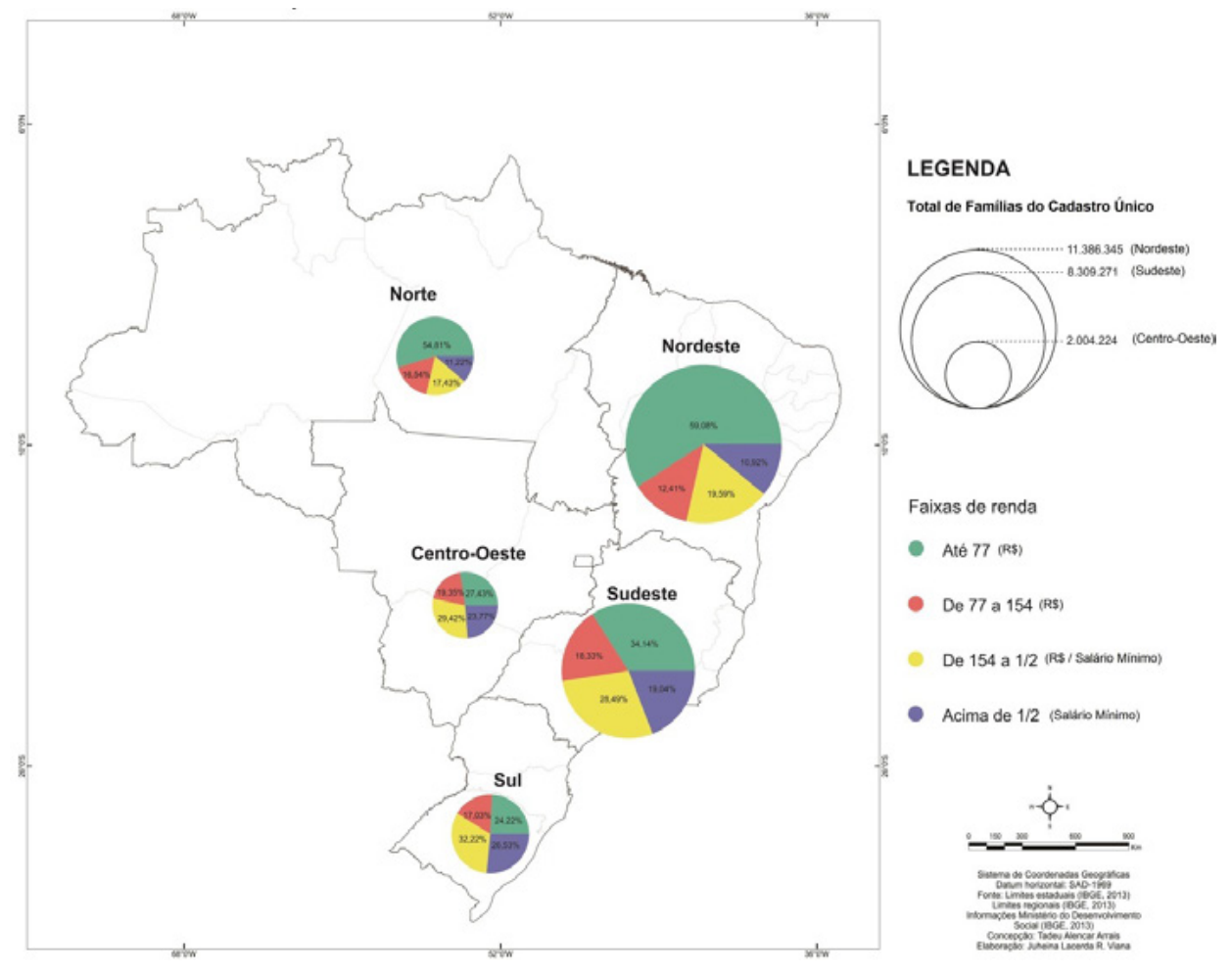

Figura 5 - Total de famílias, por faixa de renda, inscritas no Cadastro Único, 20I5. Fonte: elaboração do autor a partir de DATA-SOCIAL, 2016

A figura 5 indica faixas de renda das famílias inscritas no Cadastro Único para Programas Sociais, precondição para requerimento de benefícios sociais. Em dezembro de 2015 existiam 27.325.069 famílias inscritas, totalizando 80.954.053 pessoas cadastradas. A cobertura do Bolsa Família atingiu 50,84\% do total de famílias cadastradas, indicando demanda para expansão.

Dentre as faixas de renda per capita familiar, aquela de até $\mathrm{R} \$ 77,00$ predomina, com I2.335.278 pessoas, correspondendo a 45,I4\% do total de inscritos no Cadastro Único. Nessa faixa de renda, o Nordeste concentrava 54,53\% do total de cadastrados. O Nordeste é a região mais homogênea, considerando a participação dos estados. A média de participação na Região Nordeste para a faixa de até $\mathrm{R} \$ 77,00$ foi de $59,08 \%$, do Sudeste, 34,I4\%, do Sul, 24,22\%, e a do Centro-Oeste, 27,46\%. Ã proporção que os valores das faixas de renda aumentam, a participação relativa das famílias cadastradas no Sudeste, Sul e Centro-Oeste também aumenta. Na última faixa, acima de $1 / 2$ salário mínimo de renda per capita familiar, o Sul apresenta $26,53 \%$, o Sudeste, I9,03\%, e o Centro-Oeste, $23,77 \%$, ficando o Nordeste com I0,92\% e o Norte com Io,oI\% do total de cadastrados nas respectivas regiões. O Nordeste agrupou II.386.345 famílias, e o Sudeste, 8.309.27I famílias, no Cadastro Único. Os estados com maior número de inscritos no Cadastro Único foram São Paulo (3.621.344), Bahia (3.04I.623), Minas Gerais (2.62I.I37), Pernambuco (I.837.3II), Ceará (I.794.I79) e Rio de 
Janeiro (I.603.9I2). Os seis estados concentraram, em dezembro de 20I5, 53,I5\% das famílias brasileiras inscritas no Cadastro Único. É sobre o mapa do Cadastro Único que é construída a política de concessão de benefícios do Bolsa Família.

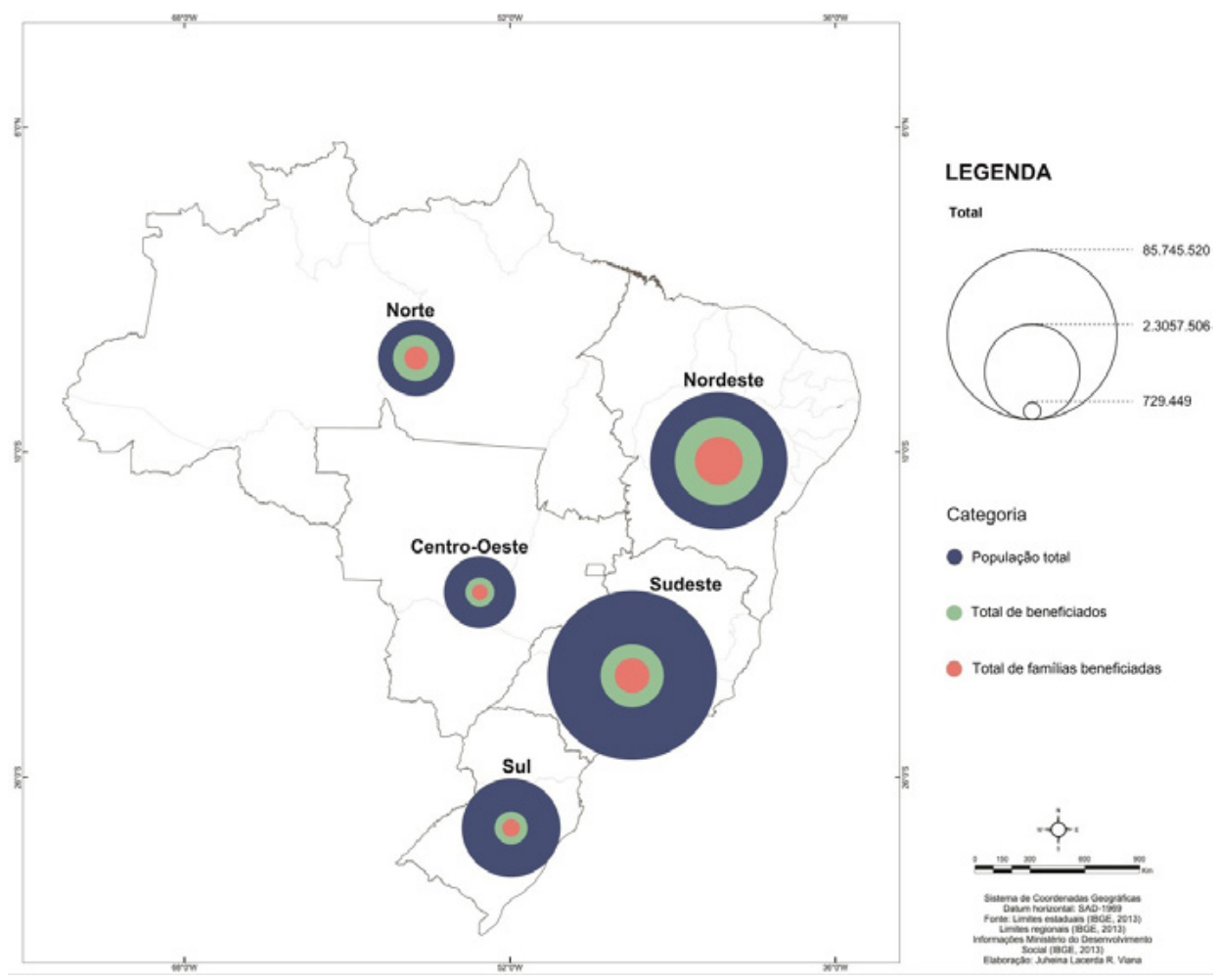

Figura 6 - População total, total de beneficiados e famílias do Bolsa Família, 20I5. Fonte: elaboração do autor a partir de DATA-SOCIAL, 2016

A figura 6 correlaciona o total da população, o número de beneficiados e o total das famílias beneficiadas. Nessa perspectiva de análise, $4 \mathrm{I} \%$ da população do Nordeste e $37 \%$ da população do Norte, em dezembro de 20I5, estavam envolvidas diretamente na rede de proteção. A média brasileira foi de $23 \%$, acima do Centro-Oeste (I6\%), do Sudeste (I4\%) e do Sul (II\%). O Nordeste concentrava 49,85\% das famílias brasileiras beneficiadas. É salutar recordar as diferenças regionais quanto à área e ao total da população. Em números absolutos, o Nordeste, com 1.794 municípios, agrupava 23.057.506 beneficiários, e o Sudeste, com I.668 municípios, agrupava II.869.953 beneficiários. As diferenças em relação aos estados comprovam o perfil regional, atestando, nessa perspectiva, a pertinência dos dados regionais. O estado com maior participação proporcional entre o total de beneficiários e o total da população foi o Maranhão, com 49,I2\%, e o de menor participação, Santa Catarina, com 6,8\%. As maiores proporções estão no Nordeste e no Norte. A média de pessoas por família beneficiada no Brasil atingiu, em 20I5, 3,42. A média mais baixa esteve no Sudeste (3,32), seguido do Nordeste (3,35). No Norte a média foi de 3,88, inferior à média de 
3,97 registrada no Sul. Esses dados, associados à progressiva redução regional da natalidade, são suficientes para colocar reticências nos argumentos sobre a influência do Bolsa Família no aumento da natalidade das famílias.

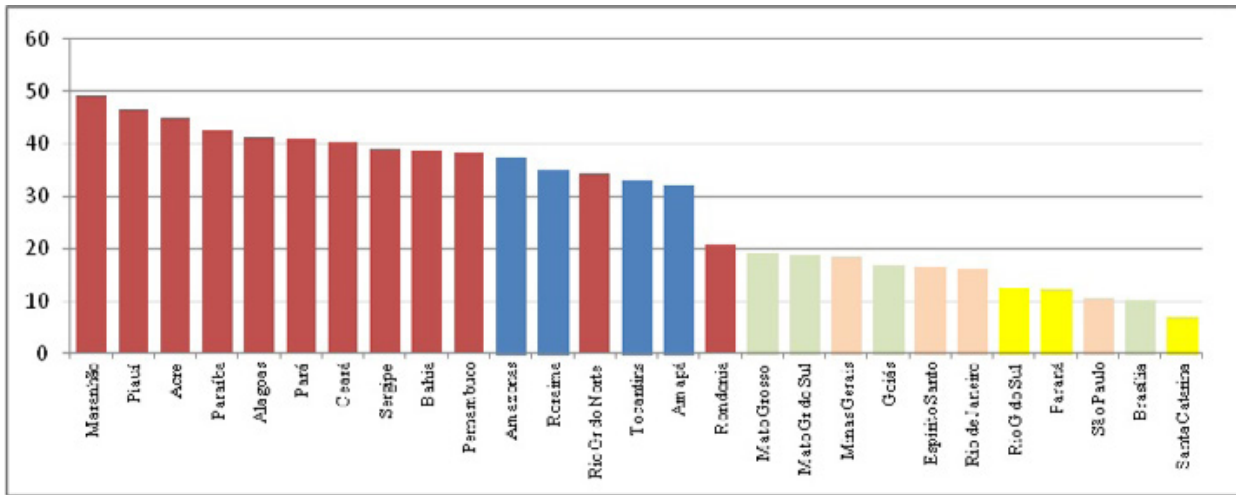

Figura 7 - Participação percentual dos beneficiários do Bolsa Família em relação à população dos estados. Fonte: dados trabalhados pelo autor a partir de DATA-SOCIAL, 20I6

A figura 8 deriva de informações sobre um perfil específico de beneficiários, denominado Grupos Populacionais Tradicionais e Específicos, composto por quatro categorias: Origem étnica (famílias quilombolas, famílias indígenas, famílias ciganas e famílias pertencentes a comunidades de terreiros), Meio ambiente (famílias extrativistas, famílias de pescadores artesanais e famílias ribeirinhas), Meio rural (agricultores familiares, assentados da reforma agrária, beneficiadas do Programa Nacional do Crédito Fundiário e famílias acampadas) e Situações conjunturais (famílias atingidas por empreendimentos de infraestrutura, famílias com pessoas no sistema carcerário, famílias em situação de rua e famílias com catadores de material reciclável). Esses grupos apresentam características ligadas à precarização do trabalho e da moradia. O total desses grupos, em janeiro de 20I6, atingiu I.43I.803 famílias, representando Io,25\% do total de famílias beneficiadas no Brasil.

Da amostra de grupos, composta por I.431.808 famílias, os benefícios rurais predominam. Das 887.332 famílias beneficiadas nesse grupo, 677.492 residiam no Nordeste. A participação rural média regional, no total dos grupos, ultrapassou $46 \%$. O Norte foi a região com menor participação rural relativa. No Sudeste, com total de 27.706 famílias, o grupo rural representou 30,6\%. Concernente ao atendimento rural, a preponderância relativa e absoluta do Nordeste guarda relação com a fragmentação territorial e com o sistema de pequena agricultura, ainda presente nas faixas do sertão e do agreste, o que indica a importante decisão de focalizar o benefício para uma população sujeita às intempéries. É oportuno destacar o peso da Aposentadoria Rural, que influencia no padrão de distribuição do Bolsa Família, uma vez que há uma inequívoca complementação de renda que, em muitos casos, ultrapassa os parâmetros de pobreza e extrema pobreza. A título de exemplo, nos estados do Maranhão, Piauí, Tocantins, Rondônia, Ceará e Paraíba, os benefícios rurais foram superiores aos urbanos, respectivamente com os seguintes percentuais: 66,86\%, 64,67\%, 59,96\%, 
56,57\%, 53,71\% e 51,74\%. Os estados com menor representação rural percentual em relação aos benefícios urbanos foram Rio de Janeiro, São Paulo, Santa Catarina, Rio Grande do Sul e Minas Gerais, com 2,55\%, 6,I7\%, 7,52\%, 23,78\%, 25,OI\% e 27,98\%, respectivamente. No entanto, em termos absolutos, o segundo grupo de estados é mais abrangente, com 2.635.I70 benefícios rurais, contra 2.47I.869 benefícios rurais do primeiro grupo. A Aposentadoria Rural influencia a distribuição dos benefícios rurais porque interfere, diretamente, na renda per capita familiar, especialmente quando se registra a presença de dois beneficiários, o que resulta em acréscimo de dois salários mínimos.

O segundo grupo de maior relevância, considerando a amostra de I.43I.808 famílias, relaciona-se ao meio ambiente. $O$ destaque é para o Norte, com percentual geral de $38,69 \%$ em relação ao total dos estados. Esse dado se explica pela força do extrativismo vegetal e da pesca, associada à predominância das famílias ribeirinhas, com um tipo de economia pouco capitalizada e sujeita às redes de exploração econômica. O Pará (48,7\%), o Amazonas (31,88\%) e o Acre (52,06\%) foram os estados com maior participação proporcional no grupo ambiental. No Pará, por exemplo, 42.897 famílias ribeirinhas e 32.014 famílias de pescadores artesanais receberam benefícios do Bolsa Família.

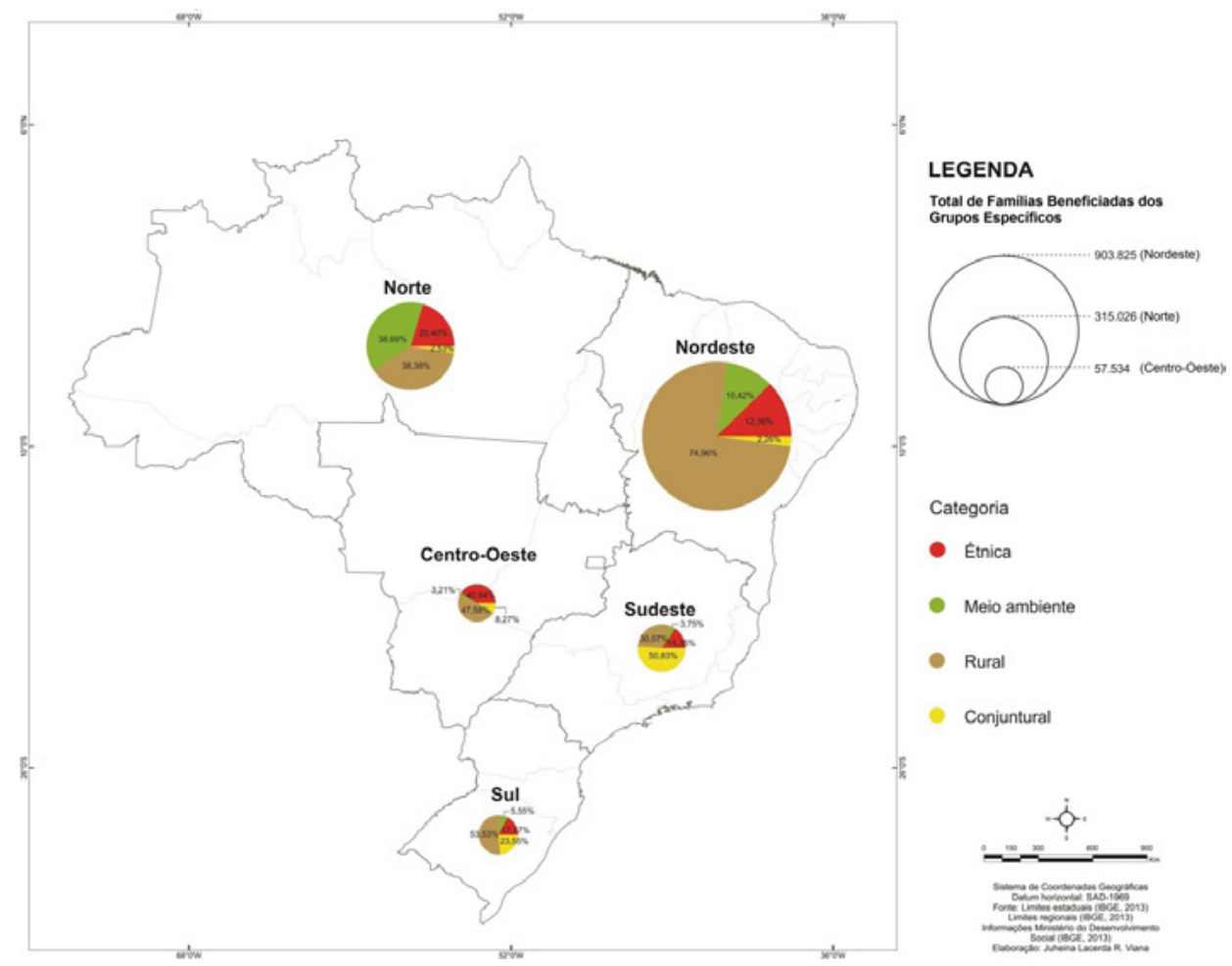

Figura 8 - Total de famílias beneficiárias do Bolsa Família, por grupos beneficiados da amostra, 20I5. Fonte: elaboração do autor a partir de DATA-SOCIAL, 2016 
O terceiro grupo da amostra é aquele de origem étnica. Do total das 224.686 famílias desse grupo, o destaque é para o Centro-Oeste, com 40,97\%, e para o Norte, com $20,4 \%$, em relação ao total das respectivas regiões. No Centro-Oeste, os estados do Mato Grosso e do Mato Grosso do Sul apresentaram, respectivamente, 4I,03\% e $54,03 \%$ do total da amostra nesse grupo. A presença de áreas indígenas justifica esse percentual. No Brasil, em 20Io, havia 896.9I7 indígenas, com concentração de 68,2\% no Norte, especialmente nos estados do Amazonas, Roraima e Pará45. No Amazonas, 29.869 famílias indígenas e 289 famílias quilombolas receberam benefícios. No Maranhão, muito embora o peso relativo não seja um dos maiores regionalmente, foram beneficiadas 28.597 famílias quilombolas. As comunidades quilombolas existem na maior parte dos estados brasileiros e não se reduzem, apenas, a enclaves rurais.

Do total dos grupos, aquele classificado como conjuntural é o de menor quantidade, com 94.868 famílias no Brasil. A despeito da menor relevância numérica absoluta, o grupo oferece indicativos sobre a focalização da precarização do trabalho e da moradia. No Sudeste esse grupo representou 50,83\% do total da região, sendo que São Paulo e o Rio de Janeiro apresentaram, respectivamente, 80,5\% e 58,3\% da participação no total dos grupos da amostra nos estados. Esse fato se explica pela presença de catadores de papel e moradores em condição de rua. Não é por acaso que o Censo da população em situação de rua de São Paulo tenha contabilizado I5.905 pessoas em situação de rua no ano de $2015^{46}$. No Norte, esse grupo apresentou 2,5\%, no Nordeste, 2,26\%, no Sul, 23,57\%, e no Centro-Oeste, 8,27\%. Brasília apresentou 72,72\%, resultado da presença de 57I famílias beneficiárias em situação de rua e 954 famílias de catadores de material reciclável. A situação conjuntural, dos grupos da amostra, é aquela que mais caracteriza o perfil urbano, somado à invisibilidade social.

Do ponto de vista absoluto, os beneficiários do Bolsa Família concentram-se nos municípios mais populosos. Não é sem razão que o município de São Paulo, em 20I5, tenha agrupado 448.908 famílias beneficiadas, o Rio de Janeiro, 245.788, Fortaleza, I98.6I5, Salvador, I97.95I, Manaus, I32.495, Recife, II6.II4, e Belém, II3.370. O conjunto das capitais estaduais concentrou, em 20I5, I3,78\% dos beneficiados brasileiros. Considerando o dado relativo, o percentual de atendimento em relação à população total aumenta à medida que a população dos municípios decresce. Com poucas exceções, essa é a tendência em todos os estados brasileiros.

O retrato espacial não demonstra apenas a heterogeneidade dos grupos sociais beneficiados, mas também a capilaridade de um programa que ultrapassa a questão regional, pelo simples fato de a pobreza, agravada pela desigualdade social, ser uma característica fundadora de nosso território.

45 BRASIL. Censo demográfico 20Io. Características gerais dos indígenas: resultado do universo. Rio de Janeiro: IBGE, $20 I 0$.

46 SÃO PAULO (Município). Censo da população em situação de rua da cidade de São Paulo, 20I5 - resultados. São Paulo: Fundação Instituto de Pesquisas Econômicas - Fipe/Secretaria Municipal de Assistência e Desenvolvimento Social - SMADS. Disponível em: <http://www.prefeitura.sp.gov.br/cidade/secretarias/ upload/assistencia_social/observatorio_social/20I5/censo/FIPE_smads_CENSO_2OI5_coletivafinal.pdf $>$. Acesso em: I4 jan. 2016 . 


\section{CONSIDERAÇõES FINAIS}

No ocaso do século XIX, pouco mais de uma década após a Proclamação da República, Affonso Celso ${ }^{47}$ publicou um livro com curioso título. Por que me ufano de meu país apresentava uma lista de onze atributos nacionais que deveriam justificar nossa superioridade. Essas razões estavam centradas na abundância de recursos naturais e em um tipo de cultura harmônica que garantiria nosso glorioso destino. No percurso do século XX encontramos outras razões para nos ufanarmos do país, como o futebol. A miséria invisível, exceto no Nordeste, parece não ter conformado, assim como o desastre diante da Alemanha na Copa do Mundo, uma barreira para o ufanismo patriótico.

Os avanços na distribuição de renda na última década, diferenciados em termos regionais, foram influenciados pela ação do Estado, da mesma forma que as ações de outrora reforçaram as assimetrias nos níveis regionais de desenvolvimento. Celso Furtado $4^{8}$, em A Operação Nordeste, alertava que o "atraso" do Nordeste não se localizava, apenas, nas questões endógenas relacionadas, por exemplo, à ausência de chuvas, que, frequentemente, desarticulava os sistemas produtivos regionais, descapitalizando os pequenos agricultores, sem redes perenes de proteção social. Celso Furtado ensinou que os subsídios, via política cambial e de crédito, favorecem São Paulo no tocante à importação de bens de capital e prejudicaram o Nordeste no tocante à exportação primária. A história da capitalização do Centro-Oeste, cujo ápice foi a edificação de Brasília, seguida do financiamento da "agricultura moderna", teve braço decisivo do Estado. O que não devemos perder de vista, antes de adotar, in totum, o discurso dualista, é que o Estado capitalizou, diferencialmente, as regiões, beneficiando, em cada uma delas, determinadas frações de classe. O economista Alain Lipietz 49 lembra que não há, propriamente, "regiões ricas" e "regiões pobres", mas relações sociais que polarizam, em cada escala, riqueza e pobreza, e as dispõem diferencialmente no espaço. Metodologicamente, o economista alerta que isso é o que se deve explicar e "não de onde se deve partir"50.

Os distintos níveis de desenvolvimento das regiões não se explicam apenas por fatores endógenos, mas, principalmente, pelo processo de integração econômica nas escalas nacional e internacional, conformando aquilo que Celso Furtado ${ }^{5 I}$ adjetivou de "interdependência estrutural" a favor de São Paulo. Historicamente, os salários foram diferenciados regionalmente, assim como o poder de compra, fundamentalmente para a base da pirâmide social. Considerando a renda dos domicílios particulares permanentes no ano de $2 \mathrm{OIO}^{52}$, por classe de rendimento, verificamos que, no Brasil, 9,I\% dos domicílios são compostos de renda de até $1 / 4$ do

47 CELSO, Affonso. Por que me ufano do meu país. 2. ed. Rio de Janeiro: Expressão e Cultura, I999.

48 FURTADO, Celso. A Operação Nordeste. Rio de Janeiro: Instituto Superior de Estudos Brasileiros, I959.

49 LIPIETZ, Alain. O capital e seu espaço. São Paulo: Nobel, I988.

50 Ibidem, p. 29.

5 I FURTADO, Celso. O longo amanhecer. 2. ed. São Paulo: Paz e Terra, I999.

52 BRASIL. Instituto Brasileiro de Geografia e Estatística - IBGE. Censo demográfico de 20Io, op. cit. 
salário mínimo per capita. Na faixa de mais de cinco salários mínimos esse percentual foi de $5,27 \%$. No Nordeste, a primeira faixa representou $20,52 \%$ dos domicílios, índice superior ao do Sudeste, que registrou 3,9\%. No extremo de mais de cinco salários mínimos, o Nordeste representou 2,45\%, e o Sudeste, 6,66\%. Essa comparação regional, no entanto, não pode camuflar a desigualdade de renda intrarregional, seja no Nordeste, seja no Sudeste. A dualidade não é uma propriedade intrínseca do espaço. A dualidade brasileira, para tomar emprestada a expressão utilizada por Galbraith ${ }^{33}$ para acentuar as relações entre a "estrutura técnica" e a "burocracia pública", não seria a mesma sem a histórica "simbiose burocrática" que uniu interesses privados e públicos. O economista cita as relações entre o Departamento de Transporte e a indústria automobilística ou, na forma mais "elevada", as relações entre o Departamento de Defesa e as empresas de armamentos como exemplos de "simbiose burocrática".

As discrepâncias de renda e oportunidades tornaram a ação do Estado determinante para diminuir as desigualdades sociais ${ }^{54}$, daí a diferença fundamental em relação ao mercado, que, por definição, não se ocupa da questão social. As evidências apontam que a questão social ganhou objetividade a partir dos anos 2000, o que redundou na construção da maior rede de assistência social da América Latina. Nesse ponto a questão social assumiu, em primeiro lugar, a função de combater a pobreza. A pobreza não é apenas, para lembrar Milton Santos ${ }^{55}$, uma categoria econômica, mas, sobretudo, uma categoria política. Como categoria econômica, seu parâmetro classificatório é a renda, muito embora os limites da mensuração da pobreza sejam conhecidos, como advertiu Sen ${ }^{56}$. Como categoria política, envolve a ação, afinal os pobres existem estruturalmente (condição do próprio capitalismo), subsistem às condições conjunturais (a pobreza aumenta nas crises), ocupam sítios ecológicos (com recursos diferenciais), não formando, apenas, um quadro estatístico estável e homogêneo, visto que são a parte mais vulnerável da nação.

A permeabilidade entre a dimensão política e a dimensão econômica fez o Bolsa Família constituir-se no programa social de maior capilaridade nacional, adquirindo, em função do curto tempo de existência, destacada centralidade na política nacional. Sua organicidade, resultado direto de sua amplitude e capilaridade, se deve, resumidamente, às seguintes características:

- A focalização a partir da renda, muito embora com críticas, encontra paralelo com outras experiências latino-americanas, afinal a renda é eficaz para saldar as demandas de consumo diário e para reverter, em curto intervalo de tempo, as situações de pobreza e extrema pobreza e, em longo prazo, associadas às políticas setoriais de educação e saúde, reverter a pobreza intergeracional.

GALBRAITH, John Kenneth. A economia e o objetivo público. São Paulo: Martins, I975.

54 POCHMANN, Márcio. O emprego no desenvolvimento da nação. São Paulo: Boitempo, 2008.

55 SANTOS, M. Pobreza urbana. São Paulo/Recife: Hucitec, I978.

56 SEN, Amartya. Desenvolvimento como liberdade. São Paulo: Cia. das Letras, 2000. 
- A centralização do programa na escala federal resultou em críticas localistas, mas também em um maior gasto do governo federal, livrando os municípios e os estados do ônus financeiro. O que está em debate, regionalmente, parece ser a paternidade e a pulverização dos investimentos. Tradicionalmente, o investimento no Nordeste concentrou-se, localmente, em grandes obras, com efeito perverso no apoderamento da gente pobre do sertão. A lógica da transferência de renda inverte esse sistema, capitalizando o beneficiário. A verticalidade, associada à pulverização, impactou positivamente nos indivíduos e nas economias locais.

- A emancipação, por meio da capitalização das famílias, é objeto de críticas constantes, especialmente quando se correlaciona o mapa do Bolsa Família com a geografia do voto. Essa perspectiva de análise implica considerar uma espécie de voto de ocasião. No entanto, seria oportuno indagar se não residiria, nesse voto regional, uma racionalidade positiva, uma vez que a população reconhece melhorias na sua vida diária. Não seria essa mesma racionalidade positiva que levaria, em outro polo, grupos de empresários a votarem em determinado governo cujo foco da política fossem os incentivos fiscais ou as privatizações?

A pedagogia da dualidade, representada, de um lado, por um Brasil moderno, construído sobre uma compreensão do trabalho e, de outro lado, por um Brasil arcaico, que sobrevive a expensas do Estado, contribuiu para sedimentar preconceitos na sociedade brasileira. Esses preconceitos emergem com mais força nos momentos de crise, responsabilizando ora os nordestinos, quase sempre, ora os mais pobres, pelo endividamento público. Todavia, o Bolsa Família não chega a ser, necessariamente, um programa revolucionário, pois sua matriz se enquadra em um tipo de liberalismo redistributivo, no sentido atribuído por Harvey57. Além disso não é um programa dispendioso - seja comparado ao PIB, pois representou, em 20I5, 0,47\%, seja comparado ao Orçamento Geral da União, pois representou, em 20I5, 0,93\% ${ }^{58}$. Nem mesmo esse capitalismo redistributivo, que entende a transferência como funcional para o mercado, parece sensibilizar nossa elite política e os segmentos da chamada "classe média", que utilizam, cotidianamente, o provérbio que advoga que "ensinar a pescar é melhor do que dar o peixe”. Mas a história ensina que muitos setores "modernos" que pescam com eficiência escondem, por conveniência, que os cardumes de atuns e salmões foram cevados pelo Estado. Essa aporia não parece constranger os liberais, que continuam a acusar o Estado de cometer o pecado de ofertar sardinhas para a parcela mais pobre da população.

57 HARVEY, David, op. cit.

58 BRASIL. Lei n. I3.II5 de 20/4/20I5. Estima a receita e fixa a despesa da União para o exercício financeiro de 20I5. Disponível em: <http://www.orcamentofederal.gov.br/orcamentos-anuais/orcamento-20I5-2/ arquivos-loa/lei-no-I3_II5_2004I5.pdf $\rangle$. Acesso em: 8 dez. 20I6; BRASIL. Instituto Brasileiro de Geografia e Estatística - IBGE. Contas nacionais trimestrais. Produto Interno Bruto - 20I5. Disponível em: <http://www. ibge.gov.br/home/estatistica/indicadores/pib/defaultcnt.shtm >. Acesso em: 8 dez. 2016. 


\section{SOBRE O AUTOR}

TADEU ALENCAR ARRAIS é pesquisador do Conselho Nacional de Desenvolvimento Científico e Tecnológico (CNPq, Nível ID), professor associado do Instituto de Estudos Socioambientais da Universidade Federal de Goiás (Iesa/UFG) e do Programa de Pesquisa e PósGraduação em Geografia da UFG.

E-mail: tadeuarraisufg@gmail.com

\section{REFERÊNCIAS BIBLIOGRÁFICAS}

ARAÚJO, T. Bacelar de. Ensaios sobre o desenvolvimento brasileiro. Rio de Janeiro: Revan, 2000.

BCB - BANCO CENTRAL DO BRASIL. Histórico de metas para a inflação no Brasil. Disponível em: <http:// www.bcb.gov.br/Pec/metas/TabelaMetaseResultados.pdf $>$. Acesso em: 20 abr. 2016.

BRASIL. Recenseamento do Brasil realizado em I ${ }^{0}$ de setembro de I920: população. Rio de Janeiro, I926. . Recenseamento geral do Brasil I950. Rio de Janeiro: IBGE, I950. . Constituição da República dos Estados Unidos do Brasil-I934. Disponível em: <http://www.planalto. gov.br/ccivil_03/Constituicao/Constituica034.htm〉. Acesso em: I6 maio 2016. . Constituição da República Federativa do Brasil I988. São Paulo: Saraiva, I99I. . Lei n. 8.742, de 7/I2/I993. Dispõe sobre a organização da Assistência Social e dá outras providências. Disponível em: <http://www.planalto.gov.br/ccivil_03/leis/L8742compilado.htm>. Acesso em: I6 maio 2016.

. Medida Provisória n. 2.I46-I, de 4/5/200I. Cria as Agências de Desenvolvimento da Amazônia e do Nordeste, extingue a Superintendência do Desenvolvimento da Amazônia - Sudam e a Superintendência do Desenvolvimento do Nordeste - Sudene, e dá outras providências. Disponível em: <http:// www.planalto.gov.br/ccivil_03/MPV/2I46-I.htm>. Acesso em: out. 2016.

. Medida Provisória n. I32, de 20/10/2003. Cria o Programa Bolsa Família e e dá outras providências. Disponível em: 〈http://www.planalto.gov.br/ccivil_03/mpv/Antigas_2003/r32.htm >. Acesso em: 20 jun. 2016.

. Instituto Brasileiro de Geografia e Estatística - IBGE. Censo demográfico de 20Io. Rio de Janeiro: IBGE, 2010.

. Censo demográfico 20Io. Características gerais dos indígenas: resultado do universo. Rio de Janeiro, IBGE, 2010.

. Lei n. I2.435, 6/7/20II. Altera a Lei n. 8.742, de 7 de dezembro de I993, que dispõe sobre a organização da Assistência Social. Disponível em: <http://www.planalto.gov.br/ccivil_03/_ato20II-20I/20II/lei/ lı2435.htm>. Acesso em: 20 jun. 2016.

. Ministério do Desenvolvimento Social e Combate à Fome. Censo SUAS 20I4. Análise dos componentes sistêmicos da Política Nacional de Assistência Social. Disponível em: <http://aplicacoes.mds. gov.br/sagi-data/METRO/metro_ds.php?p_id=495〉. Acesso em: 20 jun. 2016. 
. Lei n. I3.II5 de 20/4/20I5. Estima a receita e fixa a despesa da União para o exercício financeiro de 20I5. Disponível em: <http://www.orcamentofederal.gov.br/orcamentos-anuais/orcamento-20I5-2/ arquivos-loa/lei-no-I3_II5_2004I5.pdf $>$. Acesso em: 8 dez. 2016.

. Instituto Brasileiro de Geografia e Estatística - IBGE. Contas Nacionais Trimestrais. Produto Interno Bruto - 20I5. Disponível em: <http://www.ibge.gov.br/home/estatistica/indicadores/pib/ defaultcnt.shtm>. Acesso em: 8 dez. 2016.

CASTEL, Robert . La inseguridad social. Buenos Aires: Manantial, 2015.

As metamorfoses da questão social. Petrópolis: Vozes, 2015.

CASTRO, Josué. Geografia da fome. II. ed. Rio de Janeiro: Gryp, I992.

CEF - Caixa Econômica Federal. Atendimento. Disponível em: <http://www.caixa.gov.br/sobre-a-caixa/ Paginas/default.aspx $>$. Acesso em: I4 jun. 2016.

CELSO, Affonso. Porque me ufano do meu país. 2. ed. Rio de Janeiro: Expressão e Cultura, I999.

DATA-SOCIAL. Portal que disponibiliza dados e indicadores para elaboração de diagnósticos atualizados e para monitoramento das políticas e programas do Ministério do Desenvolvimento Social e Agrário, além de informações de contexto social, demográfico e econômico de municípios, estados, regiões e Brasil. Disponível em: 〈http://aplicacoes.mds.gov.br/sagi-data/METRO/metro.php?p_id=4〉. Acesso: maio 2016.

FRIEDMAN, Milton. Capitalismo e liberdade. Rio de Janeiro: Artenova, I977.

FURTADO, Celso. A Operação Nordeste. Rio de Janeiro: Instituto Superior de Estudos Brasileiros, I959.

. O longo amanhecer. 2. ed. São Paulo: Paz e Terra, I999.

GALBRAITH, John Kenneth. A economia e o objetivo público. São Paulo: Martins, I975.

GTDN - Grupo de Trabalho para o Desenvolvimento do Nordeste. Uma política de desenvolvimento econômico para o Nordeste. Rio de Janeiro: Departamento de Imprensa Nacional, I959.

HARVEY, David. O neoliberalismo. São Paulo: Loyola, 2008.

HAYEK, F. August. O caminho da servidão. 5. ed. Rio de Janeiro: Instituto Liberal, I990.

IPEA - Instituto de Pesquisa Econômica Aplicada. A década inclusiva (200I-20II): desigualdade, pobreza e políticas de renda. Comunicados do Ipea, n. I55, Brasília, 2012.

KERSTENETZKY, Celia Lessa. O Estado do Bem-Estar Social na idade da razão. Rio de Janeiro: Elsevier, 2012. LAMBERT, Jacques. Os dois Brasis. Io. ed. São Paulo: Nacional, I978.

LIPIETZ, Alain. O capital e seu espaço. São Paulo: Nobel, I988.

MAINON, Dália; GEIGER, P. Pinchas; BAER, Werner. O impacto regional das políticas econômicas no Brasil. Revista Brasileira de Geografia, Rio de Janeiro, ano 39, n. 3, I977.

MARTINS, José de Souza. A política do Brasil. São Paulo: Contexto, 20Ir.

MEDEIROS, Marcelo; BRITTO, Tatiana; SOARES, Fábio. Transferência de renda no Brasil. Novos Estudos - Cebrap, São Paulo, n. 79, 2007. Disponível em: <http://www.scielo.br/scielo.php?pi$\mathrm{d}=$ SoIOI-3300200700030000I\&script=sci_arttext $>$. Acesso em: I5 nov. 2007.

MORAES, R. Carmelo Correa; SILVA, M. de Paula e. O peso do Estado na pátria do mercado. São Paulo: Ed. Unesp, 20I4.

MTPS - Ministério do Trabalho. Arrecadação e benefícios emitidos pela Previdência Social nos municípios brasileiros, 20I5. Brasília: MTPS, 20I5. Disponível em: <http:/www.mtps.gov.br/dados-abertos/ dados-da-previdencia/previdencia-social-e-inss/previdencia-estatistica-por-municipio/estatisticas -municipais-20I4>. Acesso em:I2/04/20I6.

. Evolução do Salário Mínimo.- Legislação - I960-20I6. Disponível em: <http://www.mtps.gov.br/ salario-minimo/evolucao-salario-minimo . Acesso em:20/o6/20I6.

NERI, Marcelo Cortes; VAZ, Fábio Monteiro; SOUZA, P. Herculano G. Efeitos macroeconômicos do Pro- 
grama Bolsa Família: uma análise comparativa das transferências sociais. In: CAMPELLO, Tereza; NERI, Marcelo Côrtes (Org.). Programa Bolsa Família: uma década de inclusão e cidadania. Brasília, Ipea, 20I3.

OFFE, Clauss. Trabalho er sociedade. V. 2. Rio de Janeiro: Tempo Brasileiro, I99I.

OLIVEIRA, Francisco de. A questão regional: a hegemonia inacabada. Estudos avançados, São Paulo, v. 7(I8), USP, I993.

. Crítica à razão dualista: o ornitorrinco. São Paulo: Boitempo, 2003.

PNUD - Programa das Nações Unidas para o Desenvolvimento. Atlas do Desenvolvimento Municipal (20Io). Disponível em: <http://www.pnud.org.br/IDH/Default.aspx?indiceAccordion=I\&li=li_AtlasMunicipios $>$. Acesso em: 20 jun. 2016.

POCHMANN, Márcio. O emprego no desenvolvimento da nação. São Paulo: Boitempo, 2008.

POLANYI, K. A grande transformação: as origens de nossa época. Rio de Janeiro: Campus, 2000.

RANGEL, I. A história da dualidade brasileira. Revista de Economia Política, v. I(4), out.-dez. I98I.

REGO, Walquiria L.; PINZANI, Alessandro. Vozes do Bolsa Família. São Paulo: Ed. Unesp, 2013.

SANTOS, M. Pobreza urbana. São Paulo/Recife: Hucitec, 1978.

. O espaço dividido. Rio de Janeiro: Francisco Alves, I979.

SÃO PAULO. (Município). Prefeitura. Censo da População em situação de rua da cidade de São Paulo, 2015 resultados. São Paulo: Fundação Instituto de Pesquisas Econômicas - Fipe/Secretaria Municipal de Assistência e Desenvolvimento Social - SMADS. Disponível em: <http://www.prefeitura.sp.gov.br/ cidade/secretarias/upload/assistencia_social/observatorio_social/20I5/censo/FIPE_smads_CENSO_20I5_coletivafinal.pdf $>$. Acesso em: 20 jun. 2016.

SEN, Amartya. Desenvolvimento como liberdade. São Paulo: Cia das Letras, 2000.

SILVA, Maria O. da Silva. Programas de transferência de renda na América Latina e Caribe. São Paulo: Cortez, 2014 .

SUPLICY, E. Programa de Garantia de Renda Mínima. Brasília: Senado Federal, I992.

WANDERLEY, L. Eduardo W. A questão social no contexto da globalização: o caso latino-americano e o caribenho. In: BELFIORE-WANDERLEY, Mariangela; BÓGUS, Lucia; YAZBEK, M. Carmelita. Desigualdade e a questão social 4. ed. São Paulo: Educ, 2015. 